\title{
The Effect of Foreign Lending on Domestic Loans: an Analysis of U.S. Global Banks
}

Liu, Edith and Jonathan Pogach

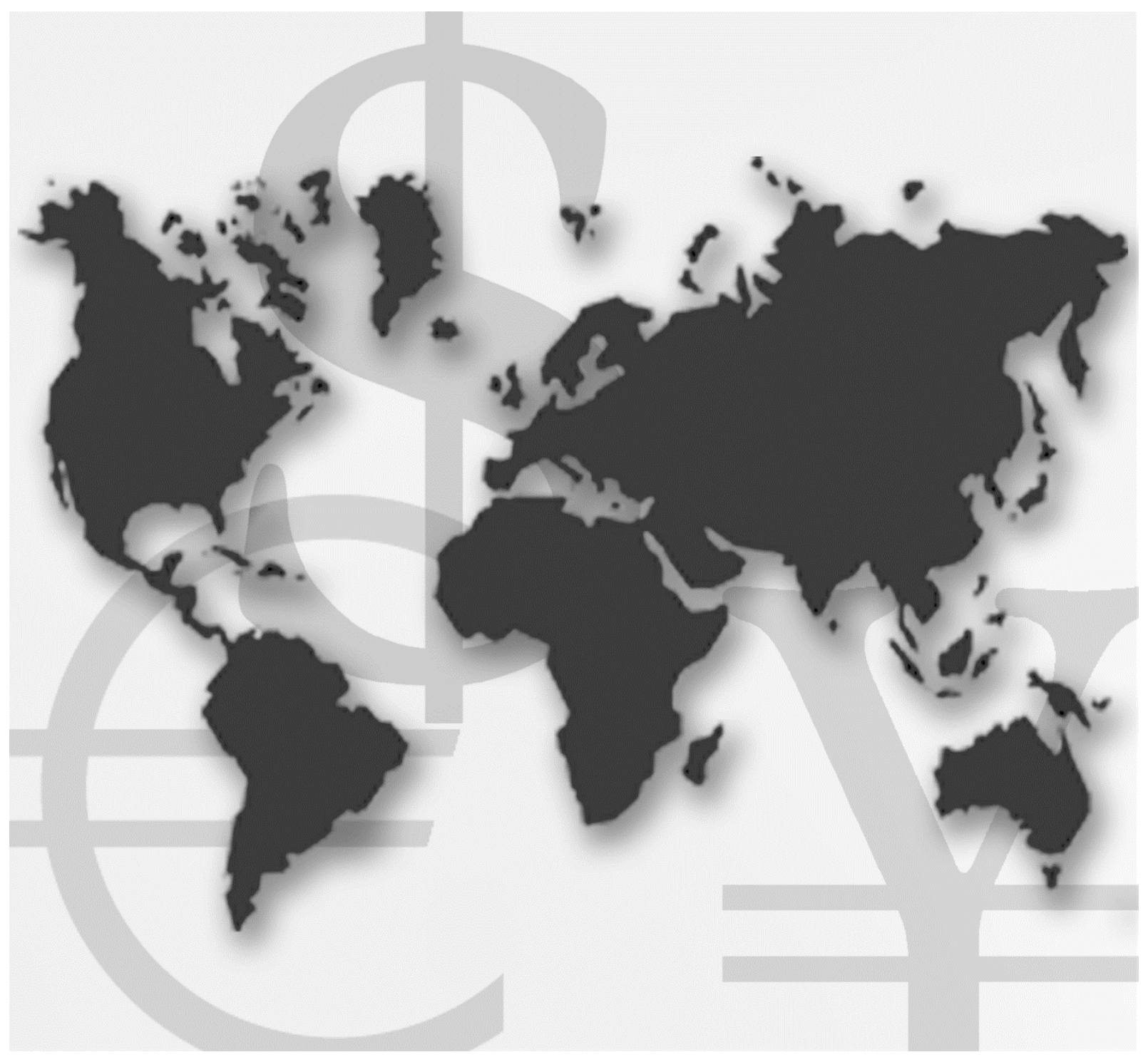

\section{International Finance Discussion Papers}

Board of Governors of the Federal Reserve System

Number 1198

February 2017 
Board of Governors of the Federal Reserve System

International Finance Discussion Papers

Number 1198

February 2017

The Effect of Foreign Lending on Domestic Loans: an Analysis of U.S. Global Banks

Edith X. Liu and Jonathan Pogach

NOTE: International Finance Discussion Papers are preliminary materials circulated to stimulate discussion and critical comment. References to International Finance Discussion Papers (other than an acknowledgment that the writer has had access to unpublished material) should be cleared with the author or authors. Recent IFDPs are available on the Web at www.federalreserve.gov/pubs/ifdp/. This paper can be downloaded without charge from the Social Science Research Network electronic library at www.ssrn.com. 


\title{
The Effect of Foreign Lending on Domestic Loans: an Analysis of US Global Banks
}

\author{
Edith X. Liu ${ }^{1}$ \\ Federal Reserve Board \\ Jonathan Pogach ${ }^{2}$ \\ FDIC
}

February 2017

\begin{abstract}
This paper examines the effect of foreign lending on the domestic lending for US global banks. We show that greater foreign loan growth complements, rather than detracts from, domestic commercial lending. Exploiting a confidential data (FFIEC 009) on international loan exposure of US banks, we estimate that a $1 \%$ increase in foreign office lending is associated with a $0.6 \%$ growth in domestic commercial lending, suggesting complementarity across these lending channels. However, when capital raising is tight during the Global Financial Crisis of 2008, we find that foreign lending did come at the expense of domestic lending.
\end{abstract}

Keywords: Multinational, Global Banking, Commercial Loans, Foreign Investments

JEL classifications: F21, F23, F36, G21

The views expressed in this paper are those of the authors and do not necessarily reflect those of the Federal Reserve Board or the FDIC. Any errors or omissions are our responsibility.

\footnotetext{
${ }^{1}$ Federal Reserve Board of Governors, $20^{\text {th }}$ and Constitution NW, Washington, DC 20035 U.S.A, (202) 452-3913 edith.x.liu@frb.gov.

${ }^{2}$ Federal Deposit Insurance Corporation, $55017^{\text {th }}$ St NW, NYA 8050, Washington, DC 20429 U.S.A., (202) 898-3653, jpogach@fdic.gov.
} 


\section{Introduction}

As of September 2014, US bank loans to non-bank borrowers outside of the US totaled \$4.9 trillion US dollars (BIS 2015). Given the large volume of cross-border loans, the impact of foreign lending may have a significant impact on the financing and growth of the US domestic economy. This paper examines US global banks and asks: does foreign lending come at the expense of domestic lending?

To understand the cross-border lending decision of global banks, it is natural to adopt the framework used for analyzing foreign and domestic real investment decisions of multinational industrial firms. ${ }^{1}$ However, the lack of available data on the geographical location of bank lending has posed a significant challenge. To this end, we exploit a confidential dataset (FFIEC 009) of US bank’s foreign country exposure and apply the methodology of Desai, Foley, and Hines (2009) to identify the relationship between foreign and domestic lending when both are simultaneously decided. ${ }^{2}$ Specifically, we construct a bank-specific exposure-weighted foreign GDP growth (also innovations to GDP growth) to instrument for foreign lending of each bank, and use the cross-sectional variation across US global banks for identification.

Our results show that US global banks treat foreign and domestic lending more as complements than substitutes, where we estimate that a $1 \%$ increase in foreign lending

\footnotetext{
1 Papers in the industrial literature include those at the macroeconomic level such as Feldstein (1995) and those at the industry level, such as Arndt, Buch, and Schnitzer (2010).

2 We assume that banks make lending decisions first, and then funds are raised to service all loans. If funds are raised first and funding is fixed, then by construction, foreign lending comes at the expense of domestic lending.
} 
corresponds to $0.6 \%$ increase in domestic loan volume. This finding mirrors the real investment complementarity found with multinational industrial firms in Desai, Foley, and Hines (2009). We view our result as the funding side counterpart of real investment made by multinational firms, and as potentially capturing the finances that follow the production side complementarities. Finally, we find that the relationship reverses when bank funding conditions tighten, thus supporting the hypothesis that when capital constraints bind then banks will necessarily trade off lending. This paper contributes to the literature on how banks allocate loan decisions across countries and relates lending patterns of global banks to those observed from real investment made by multinational firms.

\section{Model and Empirical Design}

Consider a global bank that lends in the U.S. (“Domestic”) and abroad (“Foreign”). Faced with costs, $r_{D}$ and $r_{F}$, to operate foreign and domestic loans ${ }^{3}$, the bank chooses respective loans volumes given by $L_{D}$ and $L_{F}$. The bank solves the following optimization problem, with revenue function $R\left(Q\left(L_{D}, L_{F}\right), y_{F}\right)$ and bank specific foreign lending condition, $y_{F}^{4}$ :

$$
\max _{L_{D}, L_{F}} R\left(Q\left(L_{D}, L_{F}\right), y_{F}\right)-r_{D} L_{D}-r_{F} L_{F}
$$

At the optimum, both first order conditions (FOC) on $L_{D}$ and $L_{F}$ must be satisfied simultaneously:

\footnotetext{
3 Since the bank raise funding as one entity, funding costs are the same across domestic and foreign lending. Therefore, $r_{D}$ and $r_{F}$ differ in the cost of operating loans at home and abroad.

${ }^{4}$ We assume that global U.S. banks face the same domestic lending conditions so that $\mathrm{y}_{\mathrm{F}}$ can be thought of as a bank's foreign lending conditions relative to the common domestic one.
} 


$$
\begin{gathered}
\frac{\partial R}{\partial Q} \frac{\partial Q}{\partial L_{D}}=\boldsymbol{G}\left(L_{D}, L_{F}, y_{F}\right)=r_{D} \\
\frac{\partial R}{\partial Q} \frac{\partial Q}{\partial L_{F}}=\boldsymbol{H}\left(L_{D}, L_{F}, y_{F}\right)=r_{F}
\end{gathered}
$$

where operating costs, $r_{D}$ and $r_{F}$, are parameters in the bank's decision problem. Equations (1) and (2) demonstrate that $L_{D}$ and $L_{F}$ are determined simultaneously. Therefore, a basic OLS estimate that relates changes in foreign and domestic lending, $\beta$ in the below specification, is likely to suffer from simultaneity bias:

$$
\% \Delta \text { DomesticLending }{ }_{i t}=\alpha+\beta(\% \Delta \text { ForeignLending })_{i t}+\gamma \theta_{i t-1}+\varepsilon_{i t}
$$

where $\% \Delta$ DomesticLending $_{i t}$ is the change in domestic C\&I Loans for bank $i, 5$ $\% \Delta$ ForeignLending $_{i t}$ is the change in foreign office lending 6 , and $\theta_{i t-1}$ are lagged bank specific balance sheet controls.

To address this simultaneity bias, we construct an exogenous variable to instrument for foreign lending and follow a two stage least squares (2SLS) estimation ${ }^{7}$. Following Desai et al. (2009), we define our instrument, $Z_{i t}$, to be the change in foreign GDP, weighted by the bank’s own lagged country exposures:

\footnotetext{
${ }^{5}$ We use Commercial and Industrial (C\&I) loans because it is most comparable with the investment framework for multinational firms. When we use US residential mortgage loans, we find no statistically significant relationship.

${ }^{6}$ We use Foreign Office lending, rather than Cross-Border or Total Foreign lending, because it is most closely resembles foreign direct investment of multinational industrial firms.

7 Our results do not address a separate and related question regarding the self-selection to become global. We focus on only banks that has been global through our entire sample to alleviate this bias. Further, bank balance sheet controls are included to reduce the impact of risk characteristics on the bank's operational decision.
} 


$$
Z_{i t}=\sum_{j=1} w_{i j, t-1} Z_{j t}
$$

where $z_{j t}$ is the GDP growth for country $j, w_{i j, t-1}=\frac{X_{i j, t-1}}{\sum_{j} X_{i j, t-1}}$, and $X_{i j, t-1}$ is the country exposure of bank $i$ in country $j$. Then, with our instrument, we run a 2SLS, where the regressions in each stage are specified as follows:

$$
\begin{gathered}
\% \Delta \text { ForeignLending }{ }_{i t}=a+b * Z_{i t}+c \theta_{i t-1}+\omega_{i t} \\
\% \Delta \text { DomesticLending }{ }_{i t}=\alpha+\beta *\left[\% \Delta \text { Fore } \widehat{g n L} \text { ending }_{i t}\right]+\gamma \theta_{i t-1}+u_{i t}
\end{gathered}
$$

While the above model takes the perspective of a bank's lending decision to illustrate the simultaneity bias, our identification comes from ex-ante cross-sectional differences in the foreign country exposures across US banks, and the assumption that foreign GDP growth is exogenous to the US banks. Indeed, our identification requires that a bank's foreign lending vary with their exposure to a high GDP growth country as compared to a low GDP growth country. While the positive correlation between foreign lending and foreign GDP growth can be interpreted as being driven by productivity shocks or changes in loan demand, our framework can also accommodate alternative explanations for this association. For example, a change in loan servicing cost could also induce higher GDP growth and more foreign lending into the country. For our identification strategy to be valid, we simply require that our foreign country GDP growth instrument be exogenous to the bank, and that it is correlated with the bank’s foreign lending. 


\section{Data}

Our data is based on the confidential regulatory filing FFIEC $009(\mathrm{CEX})^{8}$ that requires all US banks with $\$ 30$ million or more in foreign claims to report their exposure by country. We aggregate foreign holdings to the bank holding company (BHC) level and match balance sheet variables using the bank regulatory filing Y9C. Finally, we source real GDP growth data from both World Bank (WB) and the Penn World Tables (PWT) ${ }^{9}$. Our final sample covers the period of 1986 - 2011, excludes bank-year observations from offshore financial centers, and winsorsizes around outliers ${ }^{10}$.

We find that while foreign office loan volumes of US banks are concentrated in OECD countries and Latin America, considerable exposure differences across global banks remain. In 2012, the top countries by foreign office loan volume were United Kingdom (31\%), Japan (17\%), Mexico (7\%), Australia (5\%), Canada (5\%), and Germany (5\%), South Korea (4\%) and Brazil (4\%).

\section{Results and discussion}

Table \#1 summarizes the relationship between changes in foreign office lending and changes in domestic C\&I lending using various specifications and instruments. Column (1)

\footnotetext{
${ }^{8}$ For a detailed description of FFIEC 009, see Cetorelli and Goldberg (2012)

9 WB provides better coverage of countries in the CEX, while PWT provides PPP-adjusted GDP data that more closely follows the methodology in Desai, Foley, and Hines (2009).

10 We define outliers as observations where domestic lending or foreign office lending changed by $-50 \%$ or $+100 \%$. We define offshore financial centers from IMF report (2006).
} 
reports the basic OLS specification in Equation (3) and shows that the change in foreign office lending is positively associated with changes in domestic lending. Since the OLS estimate may be biased, the remainder of Table \#1 reports the results for the 2SLS specification, which uses weighted average foreign GDP growth or innovations to foreign GDP growth, to instrument for foreign office lending.

The first stage regression in Column (2) demonstrates the positive and highly significant $(2.309$, tstat $=3.067)$ relationship between changes in foreign office lending and our foreign GDP instrument. Absent any bank controls, Column (3) reports a positive but statistically insignificant relationship between domestic and foreign lending $(0.110$, tstat $=0.214)$. When balance sheet controls are added, Column (5) shows that a 1\% increase in foreign office lending leads to a statistically significant simultaneous increase of $0.617 \%$ in domestic lending (t-stat = 2.494). Using PPP-adjusted PWT GDP with less country coverage to construct our instrument, we find quantitatively similar results in Columns (8) - (11), but with lower statistical significance.

For robustness, we also instrument with the residual from a fitted AR(1) process for each country's GDP growth ${ }^{11}$. Column (7) of Table \#1 reports the relationship between foreign and domestic lending using the residual of WB GDP data to construct the instrument. Comparable to instrumenting with raw GDP growth, we find a statistically significant estimate of $0.689 \%$

11 The residual of foreign GDP eliminates potential bank lending decisions based on the expected GDP growth. 
on foreign office lending (tstat $=2.385)$. Similarly, residuals of PWT GDP reported in Column

(13) are comparable to the direct PWT GDP data.

The results in Table \#1 suggest that foreign lending does not come at the expense of domestic lending, but rather the two loan decisions may be strategic complements.

\subsection{The Financial Crisis of 2008-2009}

Underlying our framework is the assumption that banks make lending decisions first, and then can raise the capital to execute those loans. Otherwise, if capital is fixed, then foreign lending will necessarily come at the expense of lower domestic lending. We test this hypothesis by using the Global Financial Crisis (GFC) of 2008-2009 when banks were severely liquidity constrained and capital-raising was extremely difficult. ${ }^{12}$

Consistent with our hypothesis on binding capital constraints, we find that the relationship between foreign and domestic lending does differ during versus before the GFC. Table \#2 reports our empirical specification applied to the sample period before and during the GFC. Column (6) shows that indeed during the GFC, a 1\% increase in foreign lending leads to a 0.205\% reduction in domestic lending, although statistically insignificant ( $\mathrm{t}$-stat $=0.445$ ). When funding is scarce and banks are unable to raise capital to fund all investments, then foreign lending necessarily comes at the expense of domestic lending ${ }^{13}$. Moreover, excluding

12 Correa, Goldberg and Rice (2014) show that global banks utilized internal capital markets during the GFC to repatriate funds from abroad.

13 Substitution is consistent with flight to home results found by Giannetti and Laeven (2012) and KalemliOzcan, Papaioannou, and Perri (2013) 
the global financial crisis, Columns (2) and (4) confirms the positive relationship between foreign and domestic lending when funding can be raised to support both types of lending.

\section{Summary and conclusions}

We present new evidence that foreign and domestic lending decisions made by global banks exhibit a complimentary relationship, similar to real investment decisions made by multinational industrial firms. Exploiting a confidential dataset on individual bank foreign exposure to construct an instrumental variable for foreign lending, our analysis shows that a $1 \%$ increase in foreign lending is associated with a $0.6 \%$ increase in domestic lending. Moreover, we find that when capital-raising is limited, foreign and domestic lending instead act as substitutes.

Our results suggest that when global banks are not faced with binding funding constraints, their foreign lending activities may provide complementarities that spur domestic lending. One potential explanation for the complementarity in foreign and domestic loans may be that bank lending follows the complementarities in real side investments made by multinational firms found in Desai et al (2009). A second possibility is that global banks can lend along the supply chain, and capture the positive spillover effects, shown in Smarzynska (2004), that are passed from multinational clients to domestic suppliers of intermediate goods. Finally, new investment vehicles that securitize against pool loans across different countries require new foreign lending 
to be necessarily coupled with new domestic loans in constructing these products. ${ }^{14}$ We leave the exploration of these and other channels for continued research.

14 Aiyar, Al-Eyd, Barkbu, and Jobst (2015) summarizes the securitization of loans across countries. 


\section{References}

[1] Aiyar, S., Al-Eyd, A., Barkbu, B. and A. A. Jobst. "Revitalizing Securitization for Small and Medium-Sized Enterprises in Europe. “ IMF Staff Discussion Note, SDN/15/07.

[2] Arndt, Christian, Claudia M. Buch, and Monika E. Schnitzer. "FDI and domestic investment: an industry-level view." The BE Journal of Economic Analysis \& Policy 10.1 (2010).

[3] BIS Quarterly Review, “Highlights of global financing flows.” (2015)

[4] Cetorelli, Nicola, and Linda S. Goldberg. "Liquidity management of US global banks: Internal capital markets in the great recession." Journal of International Economics 88.2 (2012): 299-311.

[5] Correa, Ricardo, Linda S. Goldberg, and Tara Rice (2014). "Liquidity risk and U.S. bank lending at home and abroad.” Cambridge: National Bureau of Economic Research, Inc. doi:http://dx.doi.org/10.3386/w20285

[6] Desai, Mihir A., C. Fritz Foley, and James R. Hines. "Domestic effects of the foreign activities of US multinationals." American Economic Journal: Economic Policy 1.1 (2009): 181-203.

[7] Feldstein, Martin S. "The effects of outbound foreign direct investment on the domestic capital stock." The effects of taxation on multinational corporations. University of Chicago Press, 1995. 43-66.

[8] Giannetti, Mariassunta, and Luc Laeven. "The flight home effect: Evidence from the syndicated loan market during financial crises." Journal of Financial Economics 104.1 (2012): 23-43.

[10] International Monetary Fund, “Offshore Financial Centers: The Assessment ProgramA Progress Report”, Monetary and Financial Systems Department (2006).

[11] Kalemli-Ozcan, Sebnem, Elias Papaioannou, and Fabrizio Perri. "Global banks and crisis transmission." Journal of International Economics 89.2 (2013): 495-510.

[12] Smarzynska, Beata J. “Does Foreign Direct Investment Increase the Productivity of 
Domestic Firms? In Search of Spillovers through Backward Linkages.” The American Economic Review, 94.3 (2004): 605-627 
Table \#1: Foreign Office Lending and Domestic C\&I Lending

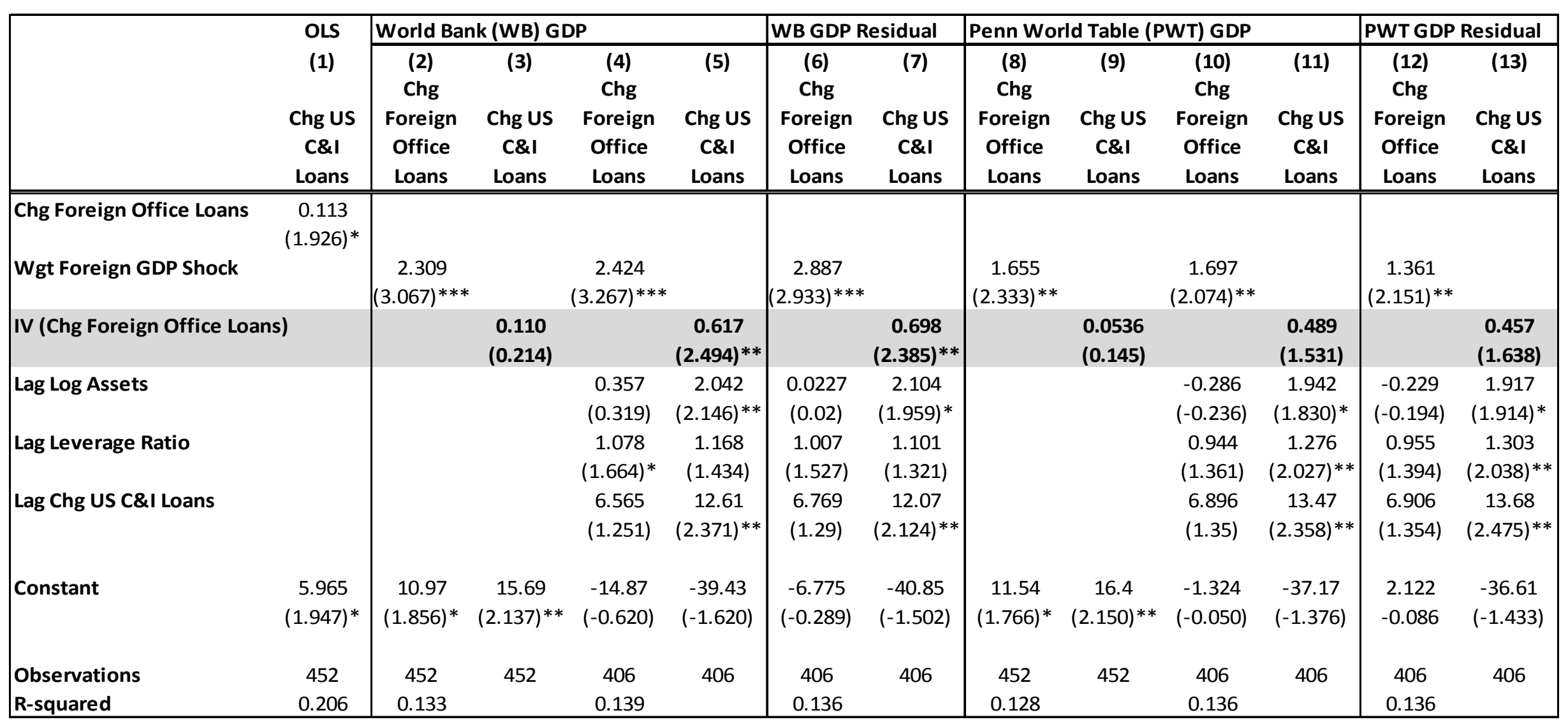

This table reports regressions of bank-country-year percentage changes of foreign lending activity on the GDP per capita growth. The Column (1) reports an OLS regression of percent change of domestic CI on weighted average percentage change in foreign office loans. Columns (2)-(5) under World Bank GDP report first (2, 4) and second (3, 5) stage regressions with and without control variables and use a World Bank derived GDP instrument for foreign office loans. Columns (8)-(11) under Penn World Table GDP growth do similarly, using a PWT derived GDP instrument. Columns (6)-(7) under WB GDP Residual and Columns (12)-(13) under PWT GDP Residual use innovations to country specific AR(1) GDP processes to derive the instrument (using their respective data sources) and report first and second stage results from this process with controls. All regressions include Year fixed effects and standard errors are clustered by bank, significance levels are ${ }^{*} \mathrm{p}<0.10$;** $\mathrm{p}<0.05 ;{ }^{* * *} \mathrm{p}<0.01$ 
Table \#2: Crisis vs No-Crisis

\begin{tabular}{|c|c|c|c|c|c|c|c|c|}
\hline & \multicolumn{2}{|c|}{ WB GDP - No Crisis } & \multicolumn{2}{|c|}{ PWT GDP - No Crisis } & \multicolumn{2}{|c|}{ WB GDP - Crisis } & \multicolumn{2}{|c|}{ PWT GDP - Crisis } \\
\hline & $\begin{array}{c}\text { (1) } \\
\text { Chg } \\
\text { Foreign } \\
\text { Office } \\
\text { Loans }\end{array}$ & $\begin{array}{c}\text { (2) } \\
\text { Chg US } \\
\text { C\&I } \\
\text { Loans }\end{array}$ & \begin{tabular}{|c|} 
(3) \\
Chg \\
Foreign \\
Office \\
Loans \\
\end{tabular} & $\begin{array}{c}\text { (4) } \\
\text { Chg US } \\
\text { C\&I } \\
\text { Loans }\end{array}$ & \begin{tabular}{|c|} 
(5) \\
Chg \\
Foreign \\
Office \\
Loans \\
\end{tabular} & $\begin{array}{c}\text { (6) } \\
\text { Chg US } \\
\text { C\&l } \\
\text { Loans }\end{array}$ & $\begin{array}{c}\text { (7) } \\
\text { Chg } \\
\text { Foreign } \\
\text { Office } \\
\text { Loans }\end{array}$ & $\begin{array}{c}\text { (8) } \\
\text { Chg US } \\
\text { C\&I } \\
\text { Loans } \\
\end{array}$ \\
\hline Wgt Foreign GDP Shock & $\begin{array}{c}2.301 \\
(2.552)^{* * *}\end{array}$ & & $\begin{array}{c}1.586 \\
(1.823)^{*}\end{array}$ & & $\begin{array}{c}4.344 \\
(1.964)^{* *}\end{array}$ & & $\begin{array}{l}1.849 \\
-0.44\end{array}$ & \\
\hline IV (Chg Foreign Office Loan & & $\begin{array}{c}0.963 \\
(2.445)^{* *}\end{array}$ & & $\begin{array}{c}0.517 \\
(1.793)^{*}\end{array}$ & & $\begin{array}{c}-0.205 \\
(-0.445)\end{array}$ & & $\begin{array}{c}-0.054 \\
(-0.054)\end{array}$ \\
\hline Lag Log Assets & $\begin{array}{c}-0.114 \\
(-0.085)\end{array}$ & $\begin{array}{c}2.209 \\
(2.063)^{* *}\end{array}$ & $\begin{array}{c}-0.471 \\
(-0.345)\end{array}$ & $\begin{array}{c}1.846 \\
(2.318)^{* *}\end{array}$ & $\begin{array}{c}5.049 \\
(1.214)\end{array}$ & $\begin{array}{c}2.232 \\
-0.911\end{array}$ & $\begin{array}{c}0.821 \\
(0.178)\end{array}$ & $\begin{array}{c}2.284 \\
(0.822)\end{array}$ \\
\hline Lag Leverage Ratio & $\begin{array}{c}1.329 \\
(2.071)^{* *}\end{array}$ & $\begin{array}{c}0.573 \\
(0.461)\end{array}$ & $\begin{array}{c}1.224 \\
(1.818)^{* *}\end{array}$ & $\begin{array}{c}1.093 \\
(1.146)\end{array}$ & $\begin{array}{c}-0.106 \\
(-0.098)\end{array}$ & $\begin{array}{c}0.762 \\
-0.479\end{array}$ & $\begin{array}{c}-0.692 \\
(-0.468)\end{array}$ & $\begin{array}{c}0.931 \\
(0.519)\end{array}$ \\
\hline Lag Chg US C\&I Loans & $\begin{array}{c}7.066 \\
(1.188)\end{array}$ & $\begin{array}{c}13 \\
(1.505)\end{array}$ & $\begin{array}{c}7.148 \\
(1.241)\end{array}$ & $\begin{array}{c}16.27 \\
(2.504)^{* *}\end{array}$ & $\begin{array}{c}0.387 \\
(0.023)\end{array}$ & $\begin{array}{l}-1.929 \\
(-0.198)\end{array}$ & $\begin{array}{l}1.272 \\
(0.09)\end{array}$ & $\begin{array}{l}-1.672 \\
(-0.158)\end{array}$ \\
\hline Constant & $\begin{array}{l}-7.278 \\
(-0.258)\end{array}$ & $\begin{array}{c}-40.54 \\
(-1.447)\end{array}$ & $\begin{array}{c}1.208 \\
(0.043)\end{array}$ & $\begin{array}{c}-33.79 \\
(-1.591)\end{array}$ & $\begin{array}{l}-102.3 \\
(-1.211)\end{array}$ & $\begin{array}{l}-67.42 \\
(-1.407)\end{array}$ & $\begin{array}{l}-12.91 \\
(-0.131)\end{array}$ & $\begin{array}{c}-70.02 \\
(-1.169)\end{array}$ \\
\hline $\begin{array}{l}\text { Observations } \\
\text { R-squared }\end{array}$ & $\begin{array}{c}373 \\
0.146\end{array}$ & 373 & $\begin{array}{c}373 \\
0.145\end{array}$ & 373 & $\begin{array}{c}33 \\
0.103\end{array}$ & 33 & $\begin{array}{c}33 \\
0.036\end{array}$ & 33 \\
\hline
\end{tabular}

This table reports regressions of bank- year percentage changes of foreign office lending activity on measures of GDP growth for the Pre US Financial Crisis years of 1985 2007 versus the Crisis years of 2008 and 2009. First and second stage results are presented pre-crisis using World Bank GDP data in the Columns (1) and (2). Columns (3) and (4) under PWT GDP-No crisis similarly present the first and second stage results using PWT GDP data. Columns (5)-(8) replicate the first four, respectively, using data only from 2008 and 2009. All balance sheet variables are lagged. All regressions include Year fixed effects and standard errors are clustered by bank, significance levels are ${ }^{*} \mathrm{p}<0.10 ; * * \mathrm{p}<0.05 ; * * * \mathrm{p}<0.01$ 